\title{
Sympatry influence in the interaction of Trypanosoma cruzi with triatomine
}

\author{
Elaine Schultz Dworak ${ }^{[1]}$, Silvana Marques de Araújo ${ }^{[1],[2], ~ M o ̂ n i c a ~ L u ́ c i a ~ G o m e s ~}{ }^{[1],[2],}$ \\ Miyoko Massago ${ }^{[2]}$, Érika Cristina Ferreira ${ }^{[1],[3]}$ and Max Jean de Ornelas Toledo ${ }^{[1],[2]}$
}

[1]. Programa de Pós-Graduação em Ciências da Saúde, Universidade Estadual de Maringá, Maringá, PR, Brasil. [2]. Departamento de Ciências Básicas da Saúde, Universidade Estadual de Maringá, Maringá, PR, Brasil. [3]. Departamento de Estatística, Universidade Estadual de Maringá, Maringá, PR, Brasil.

\begin{abstract}
Introduction: Trypanosoma cruzi, the etiologic agent of Chagas disease, is widely distributed in nature, circulating between triatomine bugs and sylvatic mammals, and has large genetic diversity. Both the vector species and the genetic lineages of T. cruzi present a varied geographical distribution. This study aimed to verify the influence of sympatry in the interaction of T. cruzi with triatomines. Methods: The behavior of the strains PR2256 (T. cruzi II) and AM14 (T. cruzi IV) was studied in Triatoma sordida (TS) and Rhodnius robustus (RR). Eleven fifth-stage nymphs were fed by artificial xenodiagnosis with $5.6 \times 10^{3}$ blood trypomastigotes $/ 0.1 \mathrm{~mL}$ of each $T$. cruzi strain. Every 20 days, their excreta were examined for up to 100 days, and every 30 days, the intestinal content was examined for up to 120 days, by parasitological (fresh examination and differential count with Giemsa-stained smears) and molecular (PCR) methods. Rates of infectivity, metacyclogenesis and mortality, and mean number of parasites per insect and of excreted parasites were determined. Results: Sympatric groups RR+AM14 and TS+PR2256 showed higher values of the four parameters, except for mortality rate, which was higher (27.3\%) in the TS+AM14 group. General infectivity was $72.7 \%$, which was mainly proven by PCR, showing the following decreasing order: RR+AM14 (100\%), TS+PR2256 (81.8\%), RR+PR2256 (72.7\%) and TS+AM14 (36.4\%). Conclusions: Our working hypothesis was confirmed once higher infectivity and vector capacity (flagellate production and elimination of infective metacyclic forms) were recorded in the groups that contained sympatric T. cruzi lineages and triatomine species.
\end{abstract}

Keywords: Trypanosoma cruzi DTU. Rhodnius robustus. Triatoma sordida. Sympatric coevolution.

Non-sympatric coevolution.

\section{INTRODUCTION}

Triatomines (Hemiptera: Reduviidae) are recognized as vectors of Trypanosoma cruzi, the etiologic agent of Chagas disease or American trypanosomiasis in Latin America ${ }^{1,2}$. This disease is considered to be the fourth most prevalent parasitic disease, with approximately 300,000 new cases registered annually. It is responsible for approximately 23,000 deaths per year ${ }^{3}$. Currently, it is estimated that approximately 6-7 million people are infected with $T$. cruzi worldwide ${ }^{4}$.

Under natural conditions, transmission of T. cruzi occurs through vectorial route, which involves contact of the vertebrate hosts with the excreta of vector bugs, contaminated with metacyclic trypomastigotes. This is the primary mechanism for the spread of the disease. The other mechanisms of transmission, referred to as the secondary mechanisms ${ }^{5}$, such as infections caused by blood transfusion, congenital transmission, and

Corresponding author: Dr. Max Jean de Ornelas Toledo.

e-mail: mjotoledo@uem.br

Received 30 May 2017

Accepted 24 August 2017 organ transplantation, in addition to the occupational and oral exposure ${ }^{6}$, are dependent on the primary mechanism. Although oral transmission is accidental, it has been considered to be responsible for the recent outbreaks of Chagas disease ${ }^{7-9}$.

The natural populations of $T$. cruzi are polyclonal and its subpopulations can be exposed to selective pressure depending on the genetic constitution of the vertebrate host ${ }^{10,11}$, different species of triatomines in which the parasites develop and circulate $^{12,13}$, and genetic constitution of these parasites ${ }^{14}$. However, some aspects of the coevolution of this parasite and vector bugs remain poorly understood ${ }^{15}$.

Different studies on the biological, biochemical, and molecular characterization of $T$. cruzi suggest that it exhibits high genetic variability ${ }^{16}$. This species has a complex population structure, with isolates distributed in six discrete typing units (DTUs), namely Trypanosoma cruzi I (TcI) to T. cruzi VI $(\mathrm{TcVI})^{17}$. TcI, TcII, TcV, and TcVI DTUs are the main agents of human Chagas disease in the Americas ${ }^{18}$. Moreover, there is a tendency for local $T$. cruzi strains to more effectively infect vectors from the same geographic areas ${ }^{19,20}$.

Sympatry is the concomitant occurrence, in space and time, of two or more different species in a given geographical 
area, resulting from total or partial overlap of their respective geographical distribution areas ${ }^{21}$. The vector species as well as the genetic lineages of $T$. cruzi vary according to the geographical area. Remarkably, the triatomine species that are most frequently found to be infected by $T$. cruzi in the State of Amazonas, Northern Brazil, belong to the genus Rhodnius whereas those in the State of Paraná, Southern region of Brazil, are Panstrongylus megistus and Triatoma sordida. In contrast, DTUs of T. cruzi found to infect humans in the Amazon region are TcI and $\mathrm{TcIV}^{22}$ whereas, in Paraná, it is mostly TcIII ${ }^{23}$. In this context, to test the hypothesis that hemoflagellate strains from a given geographical region are transmitted more efficiently by vectors from the same region than by those from another geographical area, this study evaluated the influence of sympatry on the parameters related to the biology of interaction between T. cruzi and triatomines.

\section{METHODS}

\section{Triatomines}

Triatoma sordida, currently one of the most frequently found triatomine species in Southeastern and Southern Brazil, including the State of Paraná ${ }^{24,25}$, and Rhodnius robustus, which is a vector of Chagas disease in the Brazilian Amazon region, including the State of Amazonas ${ }^{26-28}$ were used in this study (Figure 1). Colonies of these insects were kindly provided by Dr. José Jurberg of the National and International Reference Laboratory for Triatomines Taxonomy of Oswaldo Cruz Institute, Fiocruz-Rio de Janeiro, and have been kept in the insectarium of the Laboratory of Parasitology, Department of Basic Health Sciences, State University of Maringá (UEM).

\section{Strains of Trypanosoma cruzi}

Two strains of T. cruzi belonging to DTUs TcII (PR2256) and TcIV (AM14), were used. The PR2256 strain was isolated in Parana from a patient in the chronic phase of the infection, from the Municipality of Virgem de Lapa, Minas Gerais, Southeast Region of Brazil (Figure 1). The genetic lineage (DTU) of this strain was previously determined as TcII by polymerase chain reaction (PCR) of ribosomal ribonucleic acid (rRNA) gene and polymerase chain reaction/restriction fragment length polymorphism (PCR/RFLP) analyses of mitochondrial cytochrome $\mathrm{c}$ oxidase subunit II (COII $)^{23}$. The AM14 strain was isolated from an acute Chagas disease case that occurred during an oral transmission outbreak in the Municipality of Coarí, Amazonas, Northern Region of Brazil (Figure 1). It was genotyped previously as TcIV by PCR of the mini-exon and rRNA genes and by sequencing of the COII and glucose-phosphate isomerase genes ${ }^{22}$. These strains are kept cryopreserved in the Trypanosomatid Collection of the Chagas Disease Laboratory of State University of Maringá, Paraná.

\section{Experimental groups}

The strains PR2256 and AM14 were evaluated using sympatric and non-sympatric vector species, that is, in triatomines species from the same locality and a different locality (T. sordida from Paraná and $R$. robustus from Amazonas). Thus, the sympatric groups consisted of $R$. robustus and AM14 (RR+AM14) and T. sordida and PR2256 (TS+PR2256), and the non-sympatric groups consisted of $R$. robustus and PR2256 (RR+PR2256) and T. sordida and AM14 (TS+AM14).

\section{Artificial xenodiagnosis}

Eleven fifth-stage nymphs of each species were individually placed in glass containers with perforated plastic caps and made to fast for 15 days prior to the infective repast. Nymphs were experimentally infected with the aid of an artificial feeder containing mice blood with $5.6 \times 10^{3}$ blood trypomastigotes $/ 0.1 \mathrm{~mL}$ of blood. Artificial xenodiagnosis was performed with heparinized blood collected from five Swiss mice, previously inoculated through intraperitoneal route with metacyclic trypomastigotes from culture in liver infusion tryptose (LIT) medium ${ }^{29}$. Triatomines were weighed before and after the repast, during which time they were individually monitored until total repletion to determine the amount of blood ingested, considering that $1 \mathrm{mg}$ gain in weight is equivalent to $1 \mu \mathrm{L}$ of the blood ingested. Insects were kept in a biochemical oxygen demand (BOD) incubator under controlled conditions of temperature $\left(28 \pm 1{ }^{\circ} \mathrm{C}\right)$ and relative humidity $(60 \pm 5 \%)$, without illumination.

Triatomines were fed, every 20 days, with blood from uninfected mice and kept alone for $4 \mathrm{~h}$ so that spontaneous excretion could be collected. On the $30^{\text {th }}, 60^{\text {th }}, 90^{\text {th }}$, and $120^{\text {th }}$ day of infective repast, two insects from each group were dissected to collect their intestinal content. Both the biological materials were diluted in $100 \mu \mathrm{L}$ of $0.15 \mathrm{M} \mathrm{PBS}^{30}$.

\section{Parasitological and molecular evaluation}

Excreta and intestinal contents $(5 \mu \mathrm{L})$ were used to perform each of the following methods: 1) fresh examination (FE) under an optical microscope with 400X magnification ${ }^{31} ; 2$ ) global count (GC) in Neubauer chamber at a dilution of 1:100; and 3) differential count (DC) of parasitic forms in Giemsastained smears. These techniques allowed the confirmation of infection and determination of the proportion (\%) of metacyclic trypomastigotes, epimastigotes, and atypical forms (all the forms not included in the previous categories) of each insect.

The excreta and intestinal contents of insects were stored in $70 \%$ ethanol prior to deoxyribonucleic acid (DNA) extraction ${ }^{14}$ and confirmed for infection by molecular analysis through PCR. Triatomines that tested positive in at least one of four techniques used (FE, GC, DC, and PCR) were considered as infected.

\section{Polymerase chain reaction}

DNA extraction: Samples of the triatomine excreta and intestinal content were centrifuged at 2,500 rpm for $20 \mathrm{~min}$ for removing the $70 \%$ ethanol and DNA was extracted using a standard phenol chloroform method ${ }^{14,32}$. Briefly, $500 \mu \mathrm{L}$ of lysis buffer $(80 \mathrm{mM} \mathrm{NaCl} / 45 \mathrm{mM}$ ethylenediaminetetraacetic acid (EDTA), pH 8.0/1\% sodium dodecyl sulfate) supplemented with $5 \mu \mathrm{L}$ of $10 \mathrm{mg} / \mathrm{mL}$ proteinase $\mathrm{K}$ (Invitrogen, U.S.A.) was added and the resulting mixture was incubated at $37^{\circ} \mathrm{C}$ overnight. Following phenol extraction and ethanol precipitation (two volumes), the DNA was resuspended in $10 \mathrm{mM}$ Tris- $\mathrm{HCl} / 1 \mathrm{mM}$ 


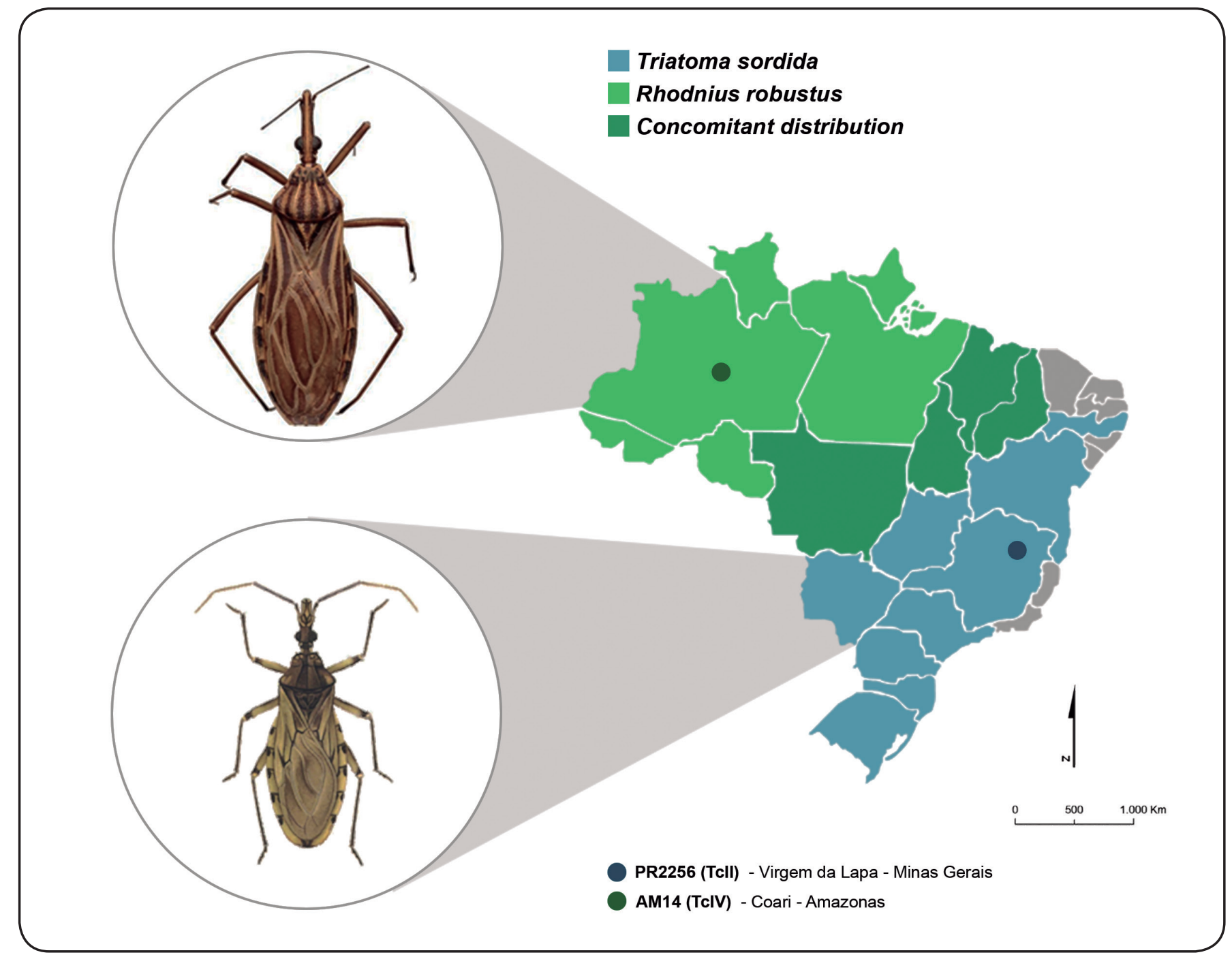

FIGURE 1 - Map of Brazil showing the geographic distribution of the triatomine species used in the study and the location where Trypanosoma cruzi infection occurs. TcII: Trypanosoma cruzi II; TcIV: Trypanosoma cruzi IV. Source: Adapted from Jurberg ${ }^{28}$.

EDTA, pH 8.0 (TE) and digested with $10 \mathrm{mg} / \mathrm{mL}$ ribonuclease A (Invitrogen) at $37^{\circ} \mathrm{C}$ for $2 \mathrm{~h}$. After another round of phenol extraction and ethanol precipitation, the DNA was again resuspended in TE buffer (10mM Tris-HCI, pH 8.0/1mM EDTA, $\mathrm{pH} 8.0$ ) and stored at $-20^{\circ} \mathrm{C}$ until use.

Amplification of the 330-base pair (bp) fragment of the minicircle: PCR was performed according to Gomes et al. ${ }^{33}$. Primers 121 (5'-AAATAATGTACGGG(T/G)GAGATGCATGA-3') and 122 (5'-GGTTCGATTGGGGTTGGTGTAATATA-3'), described by Wincker et al. ${ }^{34}$ were used to amplify a 330 -bp fragment of the kinetoplast DNA minicircle [kinetoplast deoxyribonucleic acid (kDNA)]. The PCR was processed by mixing $2 \mu \mathrm{L}$ of the DNA solution from each sample, $10 \mathrm{mM}$ Tris- $\mathrm{HCl}$ ( $\mathrm{pH} 9.0$ ), $0.1 \%$ Triton X-100, $75 \mathrm{mM} \mathrm{KCl,} 3.5 \mathrm{mM}$ $\mathrm{MgCl} 2,0.2 \mathrm{mM}$ of each of the deoxynucleotides (dATP, dCTP, dGTP, dTTP; Sigma Company Ltd.), 1U of Taq DNA polymerase (Invitrogen), and $10 \mathrm{pmol}$ of each primer for a $10-\mu \mathrm{L}$ reaction, following the protocol of Gomes et al. ${ }^{33}$. The reaction mixture was subjected to 35 amplification cycles consisting of denaturation at $95^{\circ} \mathrm{C}$ for $1 \mathrm{~min}$, annealing of primers at $65^{\circ} \mathrm{C}$ for $1 \mathrm{~min}$, and extension at $72^{\circ} \mathrm{C}$ for $1 \mathrm{~min}$, in a Techne TC-512 thermocycler. As a control for contamination during the process, for each 8 samples, 2 negative (excreta and intestinal contents of non-infected triatomines) and 2 positive (infected triatomines) original controls from the extraction step, and one negative and one positive-control for the PCR were added. Electrophoresis was performed on $4.5 \%$ polyacrylamide gels that were silverstained for visualizing the amplified DNA. The amplification of a 330-bp band suggested the presence of T. cruzi.

\section{Parameters evaluated}

The results obtained as means, using different techniques were used as parameters for the four experimental groups (RR+AM14, RR+PR2256, TS+AM14, and TS+PR2256) to determine the following: 1) Percentage of insects with positive fresh examination $(\%+\mathrm{FE}) ; 2)$ percentage of positive insects by global count $(\%+\mathrm{GC}) ; 3)$ percentage of positive insects by differential count $(\%+D C)$; and 4$)$ percentage of positive insects 
by PCR (\%+PCR). Infectivity rate was calculated considering a positive result in at least one of the four methods used. Metacyclogenesis rate was calculated by determination of the proportion of metacyclic forms in relation to the total number of parasitic forms recorded by insect. Mean parasite number in the intestinal content as well as mean the parasite number excreted per insect was determined considering the results of the $\mathrm{DC}$ technique. Mortality rate was determined considering the number of dead insects after infective repast, for up to 120 days.

\section{Statistical analyses}

Data were statistically analyzed by Bioestat ${ }^{\circledR}$ version 5.3 (Belém, Pará, Brazil). Normality was verified by the Shapiro Wilk test. Differences in proportions and comparison of means were verified by the $Z$ test. The Mann-Whitney test was used to verify the nymph weight differences before and after the infective blood meal. Statistical comparisons were performed between values obtained for each triatomine species, DTU of T. cruzi, and experimental groups (RR+AM14, RR+PR2256, TS+AM14, and TS+PR2256). A statistical significance of $5 \%$ was adopted for the tests.

\section{Ethical considerations}

Use of human-derived T. cruzi strains was approved by the Ethical Committees of Dr. Heitor Vieira Dourado Tropical Medicine Foundation (process n ${ }^{\circ} 360 / 07$ ) and of UEM (Process $\mathrm{n}^{\circ}$ 100/04 and 375/07). Experimental animals handling, maintenance, and care were in accordance with the guidelines of the National Council for the Control of Animal Experimentation (CONCEA) and approved by the Ethics Committee on the Use of Animals under Experimentation at UEM (Process n ${ }^{\circ} 023 / 2014$ ).

\section{RESULTS}

Mean weight of triatomines before and after the infective blood meal, amount of blood ingested, and mean number of blood trypomastigotes ingested per experimental group is shown in Table 1. Triatomines presented differences in weight before and after infective repast in all the groups $(\mathrm{p}<0.0001)$. In addition, the volume of blood ingested by $R$. robustus was higher than the volume of blood ingested by T. sordida $(\mathrm{p}<0.0005)$.
Mean number of ingested parasites was 10,202 and 8,334 parasites for the groups formed by $R$. robustus $+T$. cruzi II (RR+PR2256) and R. robustus + T. cruzi IV (RR+AM14), respectively. In the groups involving T. sordida, values were lower. In T. sordida + T. cruzi II (TS+PR2256), insects ingested an average of 2,464 parasites, a higher number when compared to that of T. sordida $+T$. cruzi IV (TS+AM14) which was 1,182 parasites, with a high standard deviation in the first group. The estimated number of parasites ingested by $R$. robustus was also higher when compared to T. sordida in both the groups $(\mathrm{p} \leq 0.0006)$ (Table 1).

\section{Positive results in the techniques used and infectivity rate}

The ability to detect $T$. cruzi in triatomines, independently of the vector species and parasite strain, varied significantly $(\mathrm{p} \leq 0.0005)$ with the technique used, and decreased in the order: PCR (positive in $75.1 \%$ cases) $>$ DC $(34.1 \%)>$ GC $(27.3 \%)$ $>$ FE $(25 \%)$. The positive results in PCR showed significant differences in $3 / 4$ of the experimental groups when compared to the other techniques used $(\mathrm{p} \leq 0.005)$, which showed similar results (Table 2). The sympatric group RR+AM14 showed the highest rates for all the variables indicative of triatomine infection.

Regardless of triatomine species and strain of $T$. cruzi, the overall infectivity (INF) rate was 72.7\% (32/44) (Table 2). Values of \%INF were higher in sympatric pairs, RR+AM14 $(100 \%)$ and TS+PR2256 (81.8\%), than in non-sympatric pairs, RR+PR2256 (72.7\%) and TS+AM14 (36.4\%). Proportion of infected insects was higher in the group RR+AM14 than in the group RR+PR2256. Although this difference was not significant $(p=0.07)$, there was a trend of higher \%INF in the sympatric group. The \%INF in group TS+PR2256 was statistically higher $(\mathrm{p}=0.04)$ than that in TS+AM14.

The percentages of triatomines infected with PR2256 strain of T. cruzi II and AM14 strain of T. cruzi IV over 120 days after blood repast, considering the results of excreta and intestinal contents separately, are shown in Figure 2. The \%INF was also higher in sympatric pairs, RR+AM14 and TS+PR2256, than in the non-sympatric pairs, RR+PR2256 and TS+AM14.

TABLE 1

Mean and standard deviation of insect weight before and after the blood meal, amount of blood ingested, and mean number of BT ingested per experimental group. Artificial xenodiagnosis with mouse blood infected with TcII (PR2256 strain) or TcIV (AM14 strain) containing 5.6 $\times 10^{3} \mathrm{BT} / 0.1 \mathrm{~mL}$.

\begin{tabular}{lcccc}
\hline Groups $(\boldsymbol{n}=\mathbf{1 1})$ & $\begin{array}{c}\text { Initial weight } \\
(\mathbf{m g})\end{array}$ & $\begin{array}{c}\text { Final weight } \\
(\mathbf{m g})\end{array}$ & $\begin{array}{c}\text { Amount of blood } \\
\text { ingested }(\boldsymbol{\mu} \mathbf{L})\end{array}$ & $\begin{array}{c}\text { Estimated number } \\
\text { of parasites ingested (BT) }\end{array}$ \\
\hline RR + PR2256 (TcII) & $32 \pm 12$ & $214 \pm 79^{\mathrm{a}}$ & $182 \pm 73^{\mathrm{b}}$ & $10,202 \pm 4,103^{\mathrm{c}}$ \\
RR + AM14 (TcIV) & $30 \pm 5$ & $195 \pm 46^{\mathrm{a}}$ & $149 \pm 62^{\mathrm{b}}$ & $8,334 \pm 3,488^{\mathrm{c}}$ \\
TS + PR2256 (TcII) & $86 \pm 33$ & $130 \pm 33^{\mathrm{a}}$ & $44 \pm 27$ & $2,464 \pm 1,488$ \\
TS + AM14 (TcIV) & $48 \pm 16$ & $69 \pm 21^{\mathrm{a}}$ & $21 \pm 10$ & $1,182 \pm 576$
\end{tabular}

BT: blood trypomastigotes; RR: Rhodnius robustus; TS: Triatoma sordida; $\mathbf{T c I I}$ : Trypanosoma cruzi II; TcIV: Trypanosoma cruzi IV. ${ }^{\text {a }}$ There was difference in the weights before and after the blood meal $(\mathrm{p}<0.0001)$. ${ }^{\mathbf{b}}$ There was difference in the amount of blood ingested between $R$. robustus and $T$. sordida $(\mathrm{p} \leq 0.0005)$.

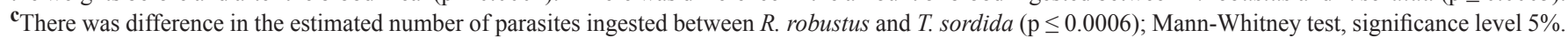


TABLE 2

Positive results of the different techniques used and rate of infectivity for Rhodnius robustus and Triatoma sordida after artificial xenodiagnosis with mouse blood infected with TcII (PR2256 strain) or TcIV (AM14 strain).

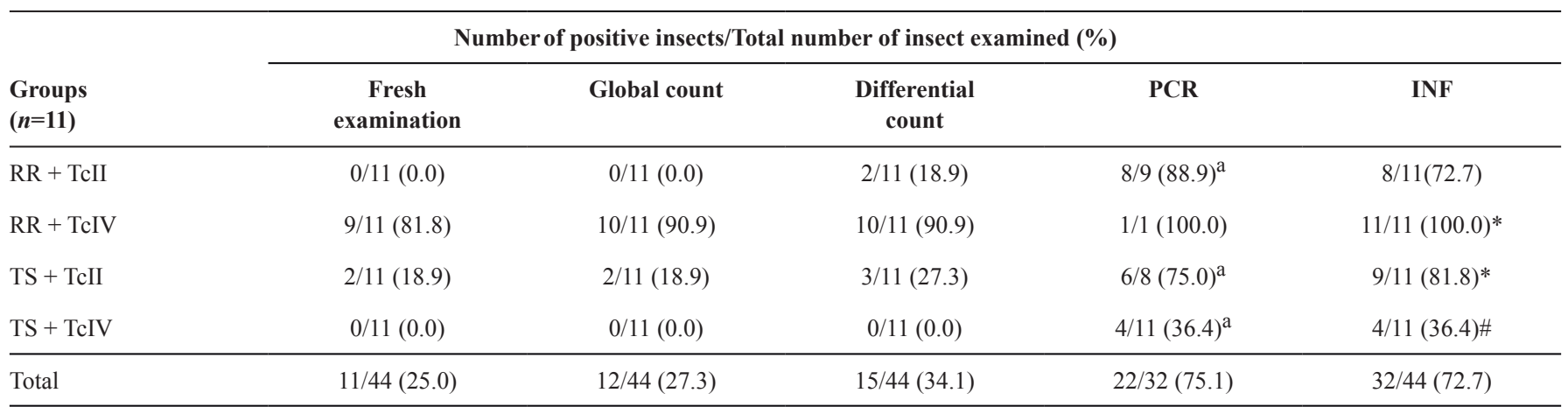

PCR: polymerase chain reaction; INF: infectivity; RR: Rhodnius robustus; TS: Triatoma sordida; TcII: Trypanosoma cruzi II; TcIV: Trypanosoma cruzi IV. ${ }^{a}$ There was difference between the rates of positive results of the techniques in the same line $(p=0.0036)$; Values with different symbols $(*$ and \#) in the same column show significant differences $(\mathrm{p}=0.04)$; $\mathrm{Z}$ test, significance level $5 \%$.

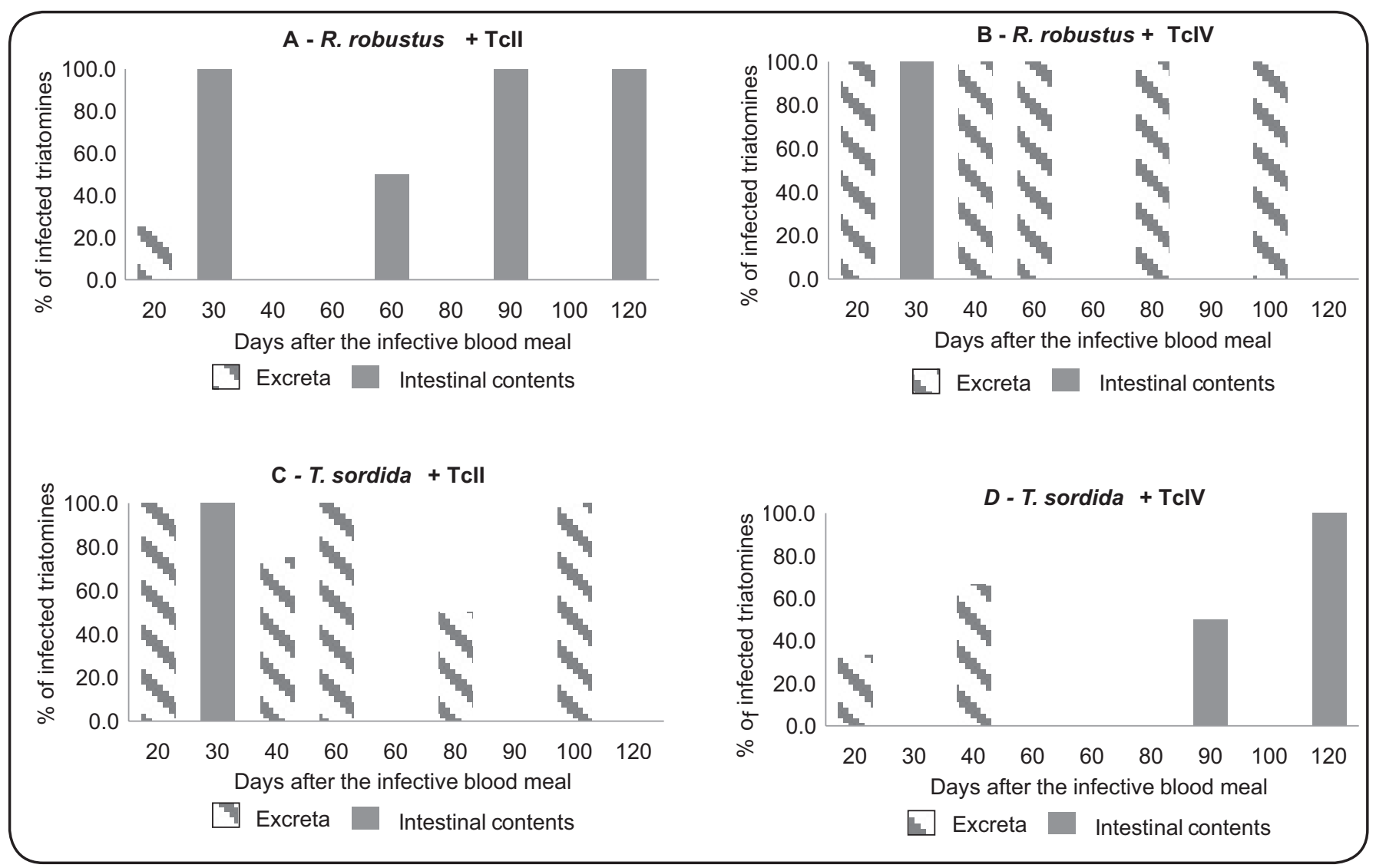

FIGURE 2 - Percentage of triatomines infected with Trypanosoma cruzi II (PR2256 strain) and IV (AM14 strain) until 120 days after blood repast. A: Rhodnius robustus + TcII. B: Rhodnius robustus + TcIV. C: Triatoma sordida + TcII. D: Triatoma sordida + TcIV. R.: Rhodnius; TcII: Trypanosoma cruzi II; T.: Triatoma; TcIV: Trypanosoma cruzi IV.

\section{Mean number of parasites per insect}

Considering both intestinal content and excreta, the mean number of parasites per insect was higher in group RR+AM14 $(4,545.5$ parasites $/ \mathrm{mL})$, followed by TS+PR2256 (3,927.3 parasites $/ \mathrm{mL}$ ) and RR+PR2256 (54.6 parasites $/ \mathrm{mL}$ ). Parasite count of insects in the non-sympatric group, TS+AM14, was null (data not shown).
Intestinal content: mean number of parasite $/ \mathrm{mL}$ in the intestinal content was higher in sympatric groups, RR+AM14 and TS+PR2256 (Figure 3A and Figure 3B). In group $\mathrm{RR}+\mathrm{AM} 14$, approximately 3,900 parasites $/ \mathrm{mL}$ were recorded in $3 / 4$ days evaluated, except on the $60^{\text {th }}$ day when the triatomines presented 2,100 parasites $/ \mathrm{mL}$. In the same group, on the $30^{\text {th }}$ day, a greater number of epimastigotes [(EP); 3,500 forms $/ \mathrm{mL}$ ] was observed, and on the $60^{\text {th }}$ day there was a predominance of 


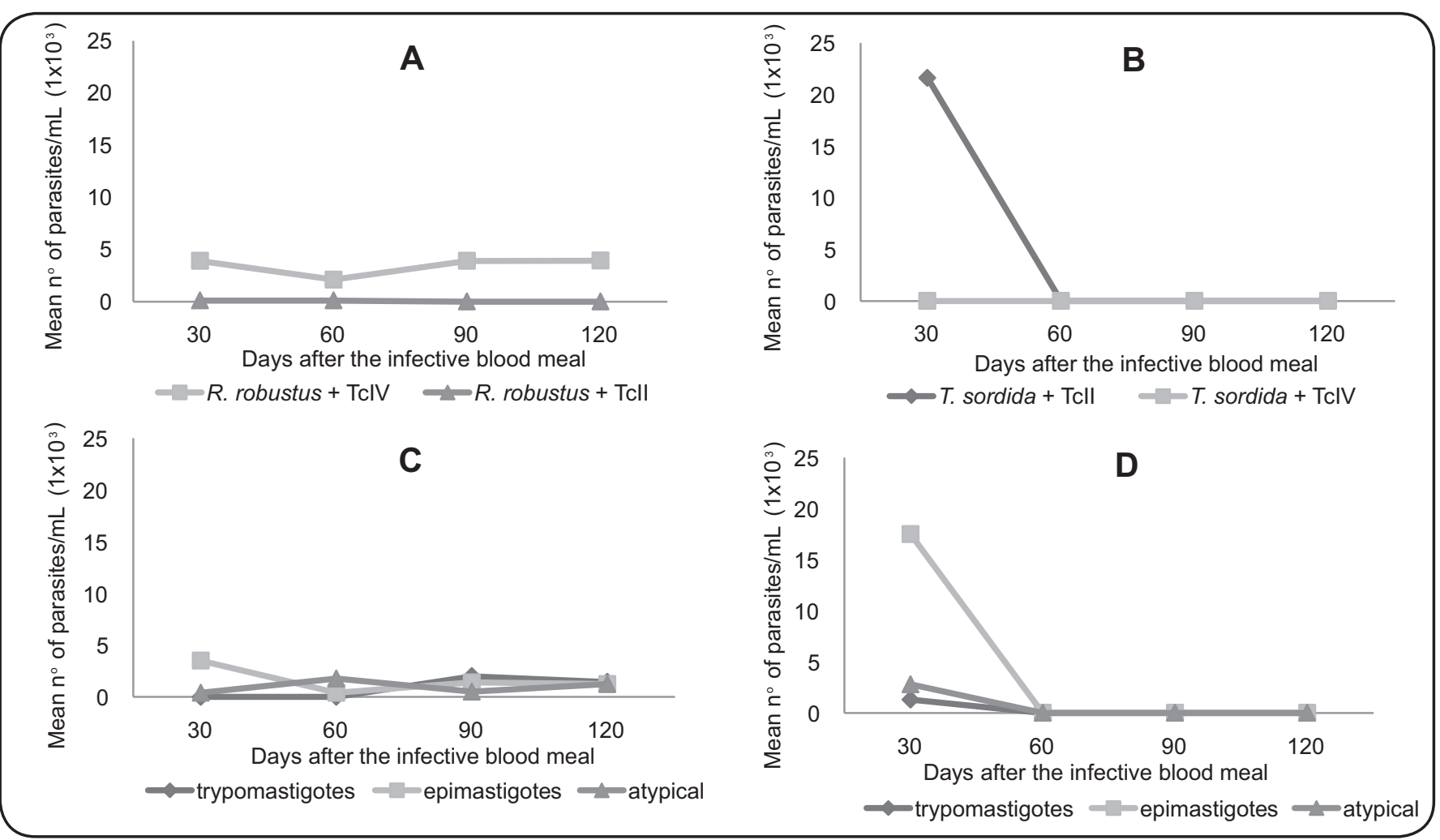

FIGURE 3 - Mean number of parasites per milliliter in the intestinal content after artificial xenodiagnosis with mouse blood infected with Trypanosoma cruzi II (PR2256 strain) and IV (AM14 strain). A: Rhodnius robustus + TcII or IV. B: Triatoma sordida + TcII or IV. C: Developmental stages in Rhodnius robustus + TcIV. D: Developmental stages in Triatoma sordida + TcII. R.: Rhodnius; T.: Triatoma; TcII: Trypanosoma cruzi II; TcIV: Trypanosoma cruzi IV.

atypical forms (AT; 1,700 forms $/ \mathrm{mL}$ ) (Figure 3C). The presence and the highest number of metacyclic trypomastigotes (MT) in the intestinal content $(2,000$ forms $/ \mathrm{mL})$ were visualized from the $90^{\text {th }}$ day onwards. The sympatric group, TS+PR2256, presented 21,600 parasites $/ \mathrm{mL}$ only on the $30^{\text {th }}$ day and was negative on subsequent evaluations (Figure 3B). There was predominance of EP forms (17,500 forms $/ \mathrm{mL})$, followed by AT (2,800 forms/ $\mathrm{mL}$ ) and $\mathrm{MT}(1,300$ forms $/ \mathrm{mL}$ ) forms (Figure 3D). Nonsympatric groups had lower concentrations of parasites in the intestinal content: RR+PR2256 with 100 parasites $/ \mathrm{mL}$ on the $30^{\text {th }}$ and $60^{\text {th }}$ day or null concentrations (TS+AM14) (Figure 3A and Figure 3B).

Excreta: Trypanosoma cruzi replication rate was only characterized in the sympatric group RR+AM14 because the parasitic forms were not observed in excreta of the other groups under the experimental conditions used.

In the RR+AM14 excreta, the highest number of parasites was observed on the $40^{\text {th }}$ day, coinciding with the highest mean number of MT (1,320 forms $/ \mathrm{mL})$, indicating a higher rate of metacyclogenesis $(95.1 \%)$. On the $60^{\text {th }}$ day, there was a decline in the mean number of MT (200 forms $/ \mathrm{mL}$ ) and increase in the AT forms (150 forms $/ \mathrm{mL}$ ), with no EP forms visualized. The number of parasites increased again on the $100^{\text {th }}$ day, with predominance of AT forms (660 forms $/ \mathrm{mL}$ ) compared to MT (400 forms $/ \mathrm{mL}$ ) and EP (226 forms/mL) forms (Figure 4).

\section{Mortality rates}

After the artificial xenodiagnosis, insect mortality rates

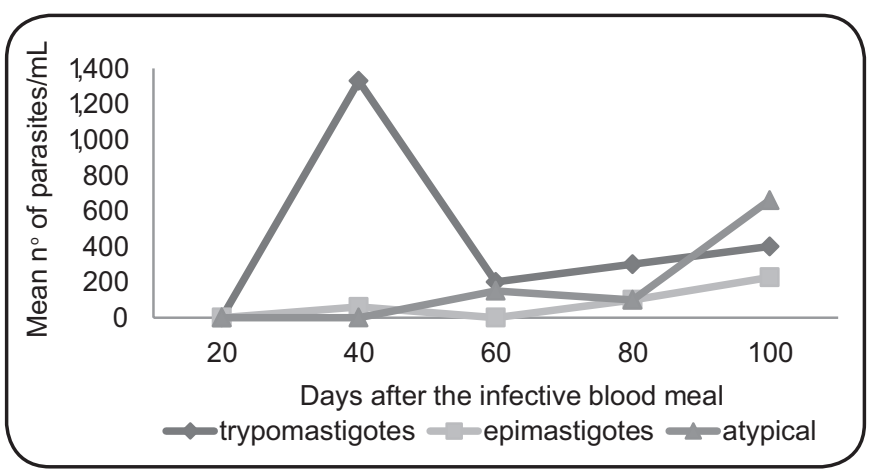

FIGURE 4 - Mean number of parasitic forms per milliliter of Trypanosoma cruzi IV (AM14 strain) present in Rhodnius robustus excreta until the $100^{\text {th }}$ day after the blood meal in artificial feeder containing infected mouse blood.

for each experimental group, observed through the first 40 days after the blood meal, were in the following decreasing order: TS+AM14 (27.4\%), TS+PR2256 and RR+PR2256 groups (18.9\%), and RR+AM14 (0\%), without any significant difference among them.

\section{DISCUSSION}

The Trypanosoma cruzi-triatomine interaction has been studied by several researchers over the years and although there are several reports ${ }^{14,35-39}$, many gaps in the knowledge about the parasite cycle in invertebrate hosts exist. However, it is clear that Chagas disease depends highly on the degree of interaction between the vector and parasite ${ }^{15}$. 
The study of sympatry in triatomines is an important parameter to evaluate the ability of $T$. cruzi to replicate and differentiate in the insect gut, because a good interaction between parasite and vector can accelerate the parasite diffusion in nature ${ }^{40}$. Results obtained in the present study demonstrate strong interaction between $R$. robustus and AM14 strain as well as between T. sordida and PR2256 strain, demonstrating that sympatry may favor both infectivity and transmission capacity of the parasite by the insect vector, because in the groups of allopatric species, which are geographically isolated ( $R$. robustus and PR2256 strain and T. sordida and AM14 strain), the infection was less efficient.

The PR2259 strain used in this study was isolated from a chronic patient residing in Paraná (PR), but the probable place of infection was in Virgem da Lapa, State of Minas Gerais (MG). In Southern and southeastern Brazil, where PR and MG states are respectively located, as well as in the Southern Cone countries of South America, TcII has been the DTU most frequently isolated from patients with chronic Chagas disease $\mathrm{e}^{41}$ and currently T. sordida is one of the most captured triatomine species.

In contrast, the AM14 strain was not isolated from the same locality as $R$. robustus triatomines used in the study, which would further favor evaluation of the sympatry influence on insect susceptibility to infection and on its vector capacity (i.e., production and elimination of infective forms). However, the AM14 strain was obtained from one acute case during an oral Chagas disease outbreak in Coarí/AM, a State where $R$. robustus species is implicated as the vector of Chagas disease ${ }^{26,27}$.

Our results are consistent with those of other authors who propose that strains of $T$. cruzi are biologically adapted to triatomine populations of the same geographic areas ${ }^{19,20,42}$. In addition, the data suggest that the infectivity of triatomine and its vector capacity might be the result of interaction of host genetics with parasite genetics, because group RR+AM14, which although ingested fewer parasites when compared to $\mathrm{RR}+\mathrm{PR} 2256$, presented higher infectivity rate. This corroborates with the results of other authors who have shown that the percentage of infection is not correlated simply with the amount of the infected blood ingested ${ }^{43,44}$.

However, experimental groups that involved $R$. robustus had a significantly higher blood volume when compared to the $T$. sordida groups and, in the case of RR+AM14, presented higher infectivity rate. Analysis of this parameter suggests that this species would be a more efficient vector in transmitting T. cruzi, with respect to the greater blood intake, the shorter time between the end of repast and first defecation, and the greater possibility of infection of a new host by the parasite ${ }^{45}$.

In this study, the spontaneous release method was used, although not all triatomines defecated during the first $4 \mathrm{~h}$ after repast. Silva et al ${ }^{46}$ demonstrated that xenodiagnostic reading by this method was more efficient than abdominal compression. A reduction in mortality by approximately three times was also observed using the spontaneous deferral method ${ }^{47}$.

In group RR+PR2256, only epimastigotes and atypical forms were observed in the intestinal content. In studies with another species of the same genus, $R$. prolixus, the findings indicated that some $T$. cruzi strains did not develop within its intestinal tract to produce metacyclic trypomastigotes, but it was able to maintain parasites in its rectal lumen ${ }^{39,48,49}$.

In many cases, under our experimental conditions, infection of the insect was only proven by PCR, demonstrating the greater capacity of detection of this technique when compared to the others. Its sensitivity can be influenced by parasite genetics, because strains belonging to different $T$. cruzi DTUs could have dissimilar DNA content and gene dosage ${ }^{50}$. Moreover, we believe that the DNA detected in the excreta and intestinal contents of the insects comes from intact, extracellular or recently destroyed parasites, indicating the persistence of parasites rather than the persistence of kDNA, as already observed in mammalian hosts ${ }^{51}$. However, the epidemiological importance of optical microscopy is evident, because it can be used to carry out differentiation of developmental stages and consequently evaluation of the rate of metacyclogenesis, an important parameter related to the capacity of species to disseminate in nature. Thus, the combination of more sensitive techniques, such as PCR with other techniques like, FE, GC, and $\mathrm{DC}$, increases the precision of the epidemiological investigation, avoiding false-negative results.

In the present study, it was not possible to characterize the $T$. cruzi replication rate in $3 / 4$ of the experimental groups. Maintenance of colonies of insects under constant temperature and humidity conditions, and the supply of feed at regular periods, changes the natural conditions, where the insects find climatic variations that influence their metabolism, trophic necessities, and consequently, the biological cycle ${ }^{52}$. These can be the cause for the disparities in the results found by several authors.

In fecal samples of $R$. robustus infected with AM14 strain, there was a predominance of trypomastigote forms, confirming occurrence of the metacyclogenesis process in this group. Metacyclic trypomastigote forms detach more easily from the intestinal wall by urine action when compared to the epimastigote forms, and are easily drawn to complete the cycle ${ }^{53}$. In the intestinal content of this group, the epimastigote and atypical forms were predominant because the tests were carried out during the periods when they were replicating and suffering differentiation in the intestine of the insect vector. Our data showed that AM14 strain interaction with $R$. robustus resulted in both the proliferative and infective forms, corroborating other result of our group (AP Abreu: personal communication).

During the course of the triatomine infection, a positive oscillation was observed in the non-sympatric groups (RR+PR2256 and TS+AM14), and on the last day of evaluation $\left(120^{\text {th }}\right.$ day), all the insects examined were positive. This suggests that the longer the incubation time, the greater was the probability of detecting T. cruzi. Therefore, a broader investigation is important in obtaining more detailed results for the understanding of what happens in nature.

It is also worth mentioning that, in the present study, a considerable mortality was observed in $3 / 4$ groups and the mortality rate was higher in T. sordida $(22.7 \%, 5 / 22)$ than in $R$. robustus $(9.1 \%, 2 / 22)$. A study that evaluated the population parameters for $T$. sordida registered high mortality, suggesting 
that approximately $50 \%$ of the insect population reaches the reproductive age in this species ${ }^{54}$. The low number of insects used for the infections (11 nymphs per group) and the examination of the intestinal contents using only two nymphs of the whole group infected is the major limitation of this study, even when considering that it was performed under similar conditions. Other authors observed a great variability when the same parameters were evaluated using different strains of T. cruzi associated with the same triatomine species.

In conclusion, under controlled temperature and humidity conditions, the experimental groups involving triatomine species and $T$. cruzi genetic lineages from the same geographic areas (or sympatric) present higher values for the mean number of parasites per insect (both in the intestinal content and excreta) and for the infectivity and metacyclogenesis rates than the groups involving geographically isolated (allopatric or nonsympatric) species. These results indicate a higher susceptibility to infection and greater vector capacity for sympatric groups association ( $T$. cruzi $\times$ triatomine vector).

\section{Acknowledgments}

We thank Dr. José Jurberg from International and National Laboratory of Reference for Triatominae Taxonomy, Oswaldo Cruz Institute, Oswaldo Cruz Foundation FIOCRUZ, Rio de Janeiro, Brazil for providing the triatomines to our laboratory.

\section{Financial support}

This work was supported by the Araucaria Foundation for Scientific and Technological Development (Grant number 10943812, 251//2014), and the National Council for Scientific and Technological Development [(CNPq) Grant number 483469/2013-0].

\section{Conflict of interests}

The author declares that there is no conflict of interest.

\section{REFERENCES}

1. Zeledon R. Vectores de la enfermedad de Chagas y sus características ecofisiológicas. Interciencia. 1983;8(6)::348-95.

2. Noireau F, Carbajal-de-La-Fuente AL, Lopes CM, Diotaiuti L. Some considerations about the ecology of Triatominae. An Acad Bras Cienc. 2005;77(3):431-6.

3. Martins AV, Gomes AP, Mendonça EG, Fietto JLR, Santana LA, Oliveira MGA, et al. Biology of Trypanosoma cruzi: an update. Infectio. 2012;16(1):45-58.

4. World Health Organization. Chagas disease (American trypanosomiasis). Geneve: WHO; 2016. Available from: http:// www.who.int/mediacentre/factsheets/fs340/en/.

5. Silveira AC, Rezende D. Epidemiologia e controle da transmissão vetorial da doença de Chagas no Brasil. Rev Soc Bras Med Trop. 1994;27(supl III):11-22.

6. Magalhães-Santos IF. Transmissão oral da doença de Chagas: breve revisão. Rev Cienc Med Bio. 2014;13(2):226-35.

7. Barbosa MGV, Ferreira JMBB, Arcanjo ARL, Santana RAG, Magalhães LKC, Magalhães LKC, et al. Chagas disease in the
State of Amazonas: history, epidemiological evolution, risks of endemicity and future perspectives. Rev Soc Bras Med Trop. 2015;48(supl I):27-33.

8. Souza-Lima RC, Barbosa MGV, Coura JR, Arcanjo ARL, Nascimento AS, Ferreira JMBB, et al. Outbreak of acute Chagas disease associated with oral transmission in the Rio Negro region, Brazilian Amazon. Rev Soc Bras Med Trop. 2013;46(4):510-4.

9. Xavier SCC, Roque ALR, Bilac D, Araújo VAL, Costa Neto SF, Lorosa ES, et al. Distantiae transmission of Trypanosoma cruzi: a new epidemiological feature of acute Chagas disease in Brazil. PLoS Neg1 Trop Dis. 2014;8(5):e2878.

10. Ramírez JD, Tapia-Calle G, Muñoz-Cruz G, Poveda C, Rendón LM, Hincapié E, et al. Trypanosome species in neo-tropical bats: biological, evolutionary and epidemiological implications. Infect Genet Evol. 2014;22:250-6.

11. Rocha FL, Roque AL, Arrais RC, Santos JP, Lima VS, Xavier SC, et al. Trypanosoma cruzi TcI and TcII transmission among wild carnivores, small mammals and dogs in a conservation unit and surrounding areas, Brazil. Parasitol. 2013;140(2):160-70.

12. Alvarenga N, Bronfen E. Integração do Trypanosoma cruzi com diferentes vetores: uso para o xenodiagnóstico. Rev Soc Bras Med Trop. 1984;17(3):145-9.

13. Zalloum L, Gomes ML, Kinoshita AT, Toledo MJO, Prioli AJ, Araújo SM. Genetic diversity of Trypanosoma cruzi natural populations in Paraná state, southern Brazil state, southern Brazil. Acta Sci Health Sci. 2007;29(1):25-31.

14. Sá ARN, Dias GBM, Kimoto KY, Steindel M, Grisard EC, Toledo MJO, et al. Genotyping of Trypanosoma cruzi DTUs and Trypanosoma rangeli genetic groups in experimentally infected Rhodnius prolixus by PCR-RFLP. Acta Trop. 2016;156:115-21.

15. Garcia ES, Ratcliffe NA, Whitten MM, Gonzalez MS, Azambuja P. Exploring the role of insect host factors in the dynamics of Trypanosoma cruzi-Rhodnius prolixus interactions. J Insect Physiol. 2007;53(1):11-21.

16. Messenger LA, Miles MA, Bern C. Between a bug and a hard place: Trypanosoma cruzi genetic diversity and the clinical outcomes of Chagas disease. Expert Rev Anti Infect Ther. 2015;13(8):995-1029.

17. Zingales B, Andrade SG, Briones MRS, Campbell DA, Chiari E, Fernandes O, et al. A new consensus for Trypanosoma cruzi intraspecific nomenclature: second revision meeting recommends TcI to TcVI. Mem Inst Oswaldo Cruz. 2009;104(7):1051-4.

18. Zingales B, Miles MA, Campbell DA, Tibayrenc M, Macedo AM, Teixeira MM, et al. The revised Trypanosoma cruzi subspecific nomenclature: rationale, epidemiological relevance and research applications. Infect Genet Evol. 2012;12(2):240-53.

19. Zeledón R. Epidemiology, modes of transmission and reservoir hosts of Chagas' disease. In: Elliott K, O'Connor M, Wolstenholme GEW, editors. Ciba Foundation Symposium 20. Trypanosomiasis and Leishmaniasis (with special reference to Chagas' disease). Chichester, UK: John Wiley \& Sons, Ltd.; 1974. p. 52-85. doi: 10.1002/9780470720035.ch4

20. Perlowagora-Szumlewicz A, Muller CA, Moreira CJC. Studies in search of a suitable experimental insect model for xenodiagnosis of hosts with Chagas' disease: 4-The reflection of parasite stock in the responsiveness of different vector species to chronic infection with different Trypanosoma cruzi stocks. Rev Saude Publica. 1990;24(3):165-77.

21. Monteiro WM, Magalhães LKC, de Sá ARN, Gomes ML, Toledo MJO, Borges L, et al. Trypanosoma cruzi IV causing outbreaks of acute Chagas disease and infections by different haplotypes in the Western Brazilian Amazonia. PLoS One. 2012;7(7):e41284. 
22. Rey L. Dicionário de termos técnicos de medicina e saúde. $2^{\mathrm{a}}$ edição. Rio de Janeiro: Guanabara Koogan; 2003. 950 p.

23. Abolis NG, Araújo SM, Toledo MJO, Fernandez MA, Gomes ML. Trypanosoma cruzi I-III in southern Brazil causing individual and mixed infections in humans, sylvatic reservoirs and triatomines. Acta Trop. 2011;120(3):167-72.

24. Toledo MJO, Kühl JB, Silva SV, Gasperi MV, Araújo SM. Estudo sobre triatomíneos e reservatórios silvestres de Trypanosoma cruzi no estado do Paraná, sul do Brasil. Resultados preliminares. Rev Soc Bras Med Trop. 1997;30(3):197-203.

25. Falavigna-Guilherme AL, Costa AL, Batista O, Pavanelli GC, de Araújo SM. Atividades educativas para o controle de triatomíneos em área de vigilância epidemiológica do Estado do Paraná, Brasil. Cad Saude Publica. 2002;18(6):1543-50.

26. Miles MA, Arias JR, de Souza A. Chagas' disease in the Amazon basin: V. Periurban palms as habitats of Rhodnius robustus and Rhodnius pictipes - triatomine vectors of Chagas' disease. Mem Inst Oswaldo Cruz. 1983;78(4):391-8.

27. Abad-Franch F, Monteiro FA. Biogeography and evolution of Amazonian triatomines (Heteroptera: Reduviidae): implications for Chagas disease surveillance in humid forest ecoregions. Mem Inst Oswaldo Cruz. 2007;102(suppl I):57-70.

28. Jurberg J, Rodrigues JMS, Moreira FFF, Dale C, Cordeiro IRS, Lamas Jr VD, et al. Atlas Iconográfico dos Triatomíneos do Brasil (Vetores da Doença de Chagas). $1^{\text {a }}$ edição. Rio de Janeiro: Instituto Oswaldo Cruz; 2014. 58 p.

29. Camargo EP. Growth and differentiation in Trypanosoma cruzi. Origin of metacyclic trypanosomes in liquid media. Rev Inst Med Sao Paulo. 1964;6(3):93-100.

30. Alvarenga NJ, Bronfen E. Metaciclogênese do Trypanosoma cruzi como parâmetro de interação do parasita com o triatomíneo vetor. Rev Soc Bras Med Trop. 1997;30(3):247-50.

31. Brener Z. Therapeutic activity and criterion of cure on mice experimentally infected with Trypanosoma cruzi. Rev Inst Med Trop Sao Paulo. 1962;4(6):389-96.

32. Macedo AM, Martins MS, Chiari E, Pena SDJ. DNA fingerprinting of Trypanosoma cruzi: a new tool for characterization of strains and clones. Mol Biochem Parasitol. 1992;55(1-2):147-54.

33. Gomes ML, Macedo AM, Vago AR, Pena SDJ, Galvão LMC, Chiari E. Trypanosoma cruzi: optimization of polymerase chain reaction for detection in human blood. Exp Parasitol. 1998;88(1):28-33.

34. Wincker P, Bosseno MF, Britto C, Yaksic N, Cardoso MA, Morel $\mathrm{CM}$, et al. High correlation between Chagas' disease serology and PCR-based detection of Trypanosoma cruzi kinetoplast DNA in Bolivian children living in an endemic area. FEMS Microbiol Lett. 1994;124(3):419-23.

35. Mello D, Chiarini C. Suscetibilidade dos diferentes estádios evolutivos de Triatoma sordida (Stal, 1859) e de Rhodnius neglectus (Lent, 1954) à infecção pelo Trypanosoma cruzi. Rev Bras Biol. 1980;40:327-34.

36. Perlowagora-Szumlewicz A, Moreira CJC. In vivo differentiation of Trypanosoma cruzi-1. Experimental evidence of the influence of vector species on metacyclogenesis. Mem Inst Oswaldo Cruz. 1994;89(4):603-18.

37. Kollien A, Schaub G. The development of Trypanosoma cruzi in triatominae. Parasitol Today. 2000;16(9):381-7.

38. Marliére NP, Latorre-Estivalis JM, Lorenzo MG, Carrasco D, AlvesSilva J, Rodrigues JO, et al. Trypanosomes modify the behavior of their insect hosts: effects on locomotion and on the expression of a related Gene. PLoS Neg1 Trop Dis. 2015;9(8):e0003973.
39. Garcia ES, Genta FA, Azambuja P, Schaub GA. Interactions between intestinal compounds of triatomines and Trypanosoma cruzi. Trends Parasitol. 2010;26(10):499-505.

40. Pereira PCM, Navarro EC. Challenges and perspectives of Chagas disease: a review. J Venom Anim Toxins Incl Trop Dis. 2013;19(1):34.

41. Freitas J, Lages-Silva E, Crema E, Pena SD, Macedo AM. Real time PCR strategy for the identification of major lineages of Trypanosoma cruzi directly in chronically infected human tissues. Int J Parasitol. 2005;35(4):411-7.

42. Ryckman RE, Folkes DL, Olsen LE, Robb PL, Ryckman AE. Epizootiology of Trypanosoma cruzi in southwestern North America. J Med Entomol. 1965;2(1):87-108.

43. Minter DM, Minter-Goedbloed E, de C Marshall TC. Comparative xenodiagnosis with three triatomine species of different hosts with natural and experimental chronic infections with Trypanosoma (Schizotrypanum) cruzi. Trans R Soc Trop Med Hyg. 1978;72(1): 84-91.

44. Perlowagora-Szumlewicz A, Muller CA. Studies in search of a suitable experimental insect model for xenodiagnosis of hosts with Chagas' disease. 1-Comparative xenodiagnosis with nine triatomine species of animals with acute infections by Trypanosoma cruzi. Mem Inst Oswaldo Cruz. 1982;77(1):37-53.

45. Sant'Anna MR, Diotaiuti L, de Figueiredo Gontijo A, de Figueiredo Gontijo NF, Pereira MH. Feeding behaviour of morphologically similar Rhodnius species: influence of mechanical characteristics and salivary function. J Insect Physiol. 2001;47(12):1459-65.

46. Silva IG, Luquetti AO, Silva HHG. Importância do método de obtenção das dejeções dos triatomíneos na avaliação da suscetibilidade triatomínica para Trypanosoma cruzi. Rev Soc Bras Med Trop. 1993;26(1):19-24.

47. Santos AH, Silva IG, Rassi A. Estudo comparativo entre o xenodiagnóstico natural e o artificial, em chagásicos crônicos. Rev Soc Bras Med Trop. 1995;28(4):367-73.

48. Mello C, Garcia E, Ratcliffe N, Azambuja P. Trypanosoma cruzi and Trypanosoma rangeli: interplay with hemolymph components of Rhodnius prolixus. J Invertebr Pathol. 1995;65(3):261-8.

49. Araújo CA, Waniek PJ, Jansen AM. TcI/TcII co-infection can enhance Trypanosoma cruzi growth in Rhodnius prolixus. Paras Vectors. 2014;7:94.

50. Schijman AG, Bisio M, Orellana L, Sued M, Duffy T, Mejia Jaramillo AMM, et al. International study to evaluate PCR methods for detection of Trypanosoma cruzi DNA in blood samples from Chagas disease patients. Plos Neglect Trop Dis. 2011;5(1):e931.

51. Tarleton RL, Zhang L. Chagas disease etiology: autoimmunity or parasite persistence? Parasit Today. 1999;15(3)94-9.

52. Curto de Casas SI, Carcavallo RU, Galíndez-Girón I, Burgos JJ. Fatores bioclimáticos e zonas de vida. In: Carcavallo RU, Galíndez Girón I, Jurberg J, Lent H, editors. Atlas of Chagas disease vectors in the Americas. 20 th edition. Rio de Janeiro: Fiocruz; 2013. p. 839-890.

53. Zeledon R, Bolaños R, Navarro M, Rojas M. Morphological evidence by scanning electron microscopy of excretion of metacyclic forms of Trypanosoma cruzi in vector's urine. Mem Inst Oswaldo Cruz. 1988;83(3):361-5.

54. Pelli A, Silva MA, Sarmento FR, Martins E, Mata SA, Domingues MA, et al. Parâmetros populacionais para Triatoma sordida Stal, 1859, o vetor mais frequente da doença de Chagas no Triângulo Mineiro (Heteroptera, Triatominae). Rev Soc Bras Med Trop. 2007;40(1):25-8. 